\title{
FREEDOM AS A CONSTITUTIONAL CATEGORY
}

DOI: $10.47743 /$ rdc-2017-1-0002

Dr.sc. Dubravko LJUBIĆ

\section{Abstract}

The history of mankind is a continuous struggle for the affirmation of man as an individual with an inviolable fundamental rights sphere, as opposed to the collectivity or some higher power. From the earliest days one had to ask and to win their autonomy, and they had to prove that they are beings with human dignity that deserve their physical and ethical individuality. The idea of the existence of the fundamental rights sphere is a legacy of the struggle against absolutism, and to respect the physical and mental integrity of every person and the protection of property rights. Fundamental rights in their implementation defend anyone to interfere with the protected sphere of the dignity of every human being. Their upgrade is formed by freedoms which authorize individuals to express their preferences and interests outside the existential sphere. Therefore, human rights and freedoms allow the individual not only to be a loyal citizen, but affect their environment and social organization, and thus affect the process of expanding personal freedoms. With constitutional affirmation of human rights and fundamental freedoms, a need emerged to define the content of these terms. In the literature, one can find a set of definitions that are more or less extensively trying to cover their ambiguity $^{2}$. It is my opinion that in an attempt at defining the concepts of

\footnotetext{
${ }^{1} \mathrm{PhD}$ in Constitutional law, Faculty of Law, University of Zagreb, Croatia. The Constitutional Court of the Republic of Croatia, Senior legal adviser - menthor Head of the Preliminary investigation procedure department.

2 Political Encyclopedia, Belgrade, 1975, pp. 510, 766: “The Fundamental Human Rights and Freedoms include the sphere of protection of physical and personal integrity of a person as a human being, and a guarantee of their socio-political expression and expression of thought active existentiality of a man".

- Smerdel/Sokol, Constitutional Law, Zagreb, 2006, p. 101: "Human rights imply a set of fundamental authorities of individuals to require certain actions of public authorities, whether it is to refrain from resorting to the protected sphere of the individual, as it is the case with personal and political freedoms and rights, or the active work of the realization of certain guarantees freedoms and rights, as it is the case with social, cultural and economic rights".

- In the literature, it is not rare that the terms "constitutional right", "constitutional freedom" and "constitutional guarantee" are treated as synonyms. For example, see D. Vrban, State and Law, Zagreb, 2003, p. 181: "The so-called «basic or fundamental constitutional rights» are an expression or political-legal formulation of general or natural rights and freedoms. (...) Fundamental rights are therefore guarantees that extend to all members of a political community or country who have the status of citizens, and they relate to equality before the law, protection of personal freedom and integrity, the right to property, freedom of expression (thought), the right of association, the selection of political representatives and so on".
} 
"human rights" and "fundamental freedoms" it is appropriate to start from the indications of their legal origin. The development of democratic societies to the current civilization level has enabled the codification of the fundamental rights sphere at the national and international level. The catalog of fundamental human rights and freedoms in principle is an integral part of the highest legal act of a country ${ }^{3}$, and sometimes constitutions point to the recognition of human rights and freedoms determined by international legal acts ${ }^{4}$.

In attempting to define the observed concepts it seems justified to stress that fundamental human rights and freedoms belong to every individual, regardless of his personal characteristics and status and that those rights and freedoms affirm the individual as a human and social being. It is also necessary to point out that the declaration of fundamental human rights and freedoms in the highest legal acts of some social community commits the state government to refrain from interfering in the protected sphere. In conclusion, when defining the analyzed content it is necessary to note that human rights and freedoms in principle are not absolute categories. These are constitutional activities to be limited following the existence of the rights of another individual of the same content, or the rights of others, arising from the fact of living together. Following these settings the definition of content of concepts of "constitutional law" and "constitutional freedoms" would have its common and special part. Common components of those institutes are contained in the fact that this is the highest legal act of a society or by this act defined norm of international law, established inviolable autonomous sphere of each member of society, which enables them recognition as human and social beings and that they enjoy regardless of their status and other personal characteristics, protected from encroachment by any governmental body. In doing so, the concept of "constitutional rights" should be more linked to the protected goods that are immanent to a person as a human being and granted to them but by the very fact of existence. By contrast, constitutional freedoms would include a

\footnotetext{
3 For example, the Croatian Constitution mentions human rights and freedoms in Chapter III, entitled "Protection of human rights and fundamental freedoms". The Constitution of Romania elaborates human rights and freedoms in the Section II, entitled "Fundamental Rights, Freedoms and Duties". GG contains the fundamental rights of citizens in the Head I, called "Fundamental Rights", while the Constitution of Bosnia and Herzegovina contains a list of rights and fundamental freedoms in Article II/3, titled "List of Rights".

4 For example, Article 141 of the Croatian Constitution states: "International agreements that have been concluded and ratified in accordance with the Constitution and made public, and which are in force, shall be part of the internal legal order of the Republic of Croatia, and by their legal force are above the law. Their provisions may be changed or repealed only under conditions and in the manner specified in them or in accordance with the general rules of international law". Article 25 of the GG reads: "General norms of international law are an integral part of federal law. They have greater legal force then laws, but they make possible direct rights and obligations of citizens of the Federal Republic of Germany". Article II/2 of the Constitution of Bosnia and Herzegovina reads: "In Bosnia and Herzegovina rights and freedoms guaranteed by the European Convention for the Protection of Human Rights and Fundamental Freedoms and its Protocols are directly applicable. These shall have priority over all other laws".
} 
protected sphere of the individual in social contacts. Constitutional freedoms would be an institutionally protected sphere of the individual, as a result of his life in the community, which gives them a choice in social positioning and which can only be restricted by rights of another individual of the same content, or the rights of other people arising from the fact that they are living together.

Keywords: human fundamental rights and freedoms; Constitution; human being; democratic society; international law; internal law

\section{Introduction. The content of the concept of "freedom"}

In the political context the concept of "liberty" is a possibility of choice that should be offered as an upgrade to an individual's natural rights. Freedom primarily determines borders of actions of public authorities, but also the limits of action of other people due to the fact of living together. The term "freedom" is used when it can better express manifestation of a specific right which is bounded by a measure of independence of a person in the exercise and enjoyment of that right because every right is at the same time a source of freedom. Therefore, freedom is undoubtedly one of the most studied sociological phenomena in the history of mankind as an inspiration of human creativity, the ideal of social order, i.e. the foundation of every individual battle. At the individual level, freedom enables independent action and self-determination of a person. It means a state of limitlessness, non-imprisonment, or the condition inherent to a person due to a fact of possessing humanity and consciousness, with the addition that every legally regulated social relationship implies somewhat limiting freedom. The ideal of freedom is the driving force of human activity, the basis of social equality within a constitutional state, while social restriction of the freedom of the individual must and should be allowed only to stop the prevention of exercise of freedoms of other equals, and subject to that, to achieve social goals. However, freedom can not have the meaning of power to take action in the absence of responsibility. Being free does not mean being irresponsible for ones behavior, but freedom is a choice of conduct up to the limit of liability conditioned by social norms.

Historically at the beginning of the development of human society individual freedom depended exclusively on social Darwinism. The weak were subordinate to the strong and the physical force of the individual or the pack was the basis of social relations primarily based on the principle of domination. The lack of freedom or its restriction, depending on the brutality that a certain epoch of social relations established on the basis of general inequality carried with it, ranged from treatment of individuals as things with a voice up to the legal position of semi-free producers who were obliged by the law to give generous contributions of labor and military service and financial benefits to eligible individuals or social groups. 
With the advent of the market economy and capitalist social relations, the source of freedom limitation moves from the domain of physical force to the field of economic coercion. Civil society becomes a social force, whether through evolution or revolution, changing the social order based on overall inequality. Prerequisites of development of civil society were reaching a basic level of equality that we all gain by birth, and defining the scope of fundamental freedoms inalienable from their holders through measures which abolish the essence of freedom itself. In doing so, the concept of "freedom" is used to achieve a choice that is and must be offered to individuals as an integral element of their personality. Here freedom determines the limits of the powers of the individual in social activities and also indicates an area protected from disproportionate state intervention aimed at achieving public interest. Until the emergence of civil society the relationship between the state and the individual was solved solely by the will of the state and a narrow circle of government. With the development of states based on the universal values of freedom and equality at the end of $18^{\text {th }}$ century, freedom becomes a measure of organization of social relations and the foundation of human existence. In modern social systems based on individual freedom and equality of its citizens the area of freedom is characterized by the possibility of action and behavior of every person, protected by the intervention of the state and its bodies. Freedom becomes a basic feature of human existence and basic human value, which is the object of every constitutional order. It is the counterbalance of collectivist notions of society and prevents any totalitarian control and directing of people as there is no free community without the free individual, whereby the social power is legitimate to the extent that it frees people from the fear of lack of freedom. Freedom is the cause due to which existence the individual or social groups, generally retain the ability to act independently on the inner discipline and external ethical or social customs. The concept of "freedom" in its content does not include irresponsible independence because freedom entails obligations, whereat responsibility and commitment to the freedom of another person are at the forefront. It empowers individuals to express their affinity and interests outside the existential sphere. It represents the possibility of self-determination devoid of external pressures, whereat its unconditional nature and integrity is proportional to individual responsibility for what is done, without the possibility of calling for any form of collective guilt ${ }^{5}$.

\section{Philosophical definition of the concept of "freedom"}

Even in ancient times there is the first thinking about the rights and freedoms immanent to man. Of course, in the ancient thought the idea of a general, fundamental rights sphere recognized by everyone was unknown, because then the social regimes

\footnotetext{
5 See: A. Fira, Constitutional Law, Belgrade, 1979, p. 266; A. Bačić, Constitutional Law of the Republic of Croatia, Practicum, Split, 2006, p. 132; J. Đorđević, Political Systems, Belgrade, 1977, p. 963.
} 


\section{Dubravko LJUBIĆ}

were based on the Institute of slavery. The knowledge and the definition of the integral concept of "freedom" in the sphere of philosophical and ethical considerations has not met with understanding of political elites, leading to cognitive achievements not having an empirical value. By the $5^{\text {th }}$ century $\mathrm{BC}$ social activities did not constitute an object of special consideration. Appearances in the society were to observers the outcome of unpredictable facts of reality, and as such unfathomable to rational knowledge. During this period, all causes and effects have been attributed to the autonomous will of the gods, and on such perception of the society a variety of theocratic schools have been developed. In the Hellenic world begins a deeper rationalization of nature and society. There indeed the reflection does not destroy the relationship with the gods, but it greatly rationalizes not only the world of the gods, but also the secular world. We can see the embryo of debate about freedom in the teachings of sophist who thought that the natural right is higher and better than the existing laws, and that God created all men free and that he made nobody a slave. The idea of freedom is based on the duality of freedom of the citizen and the state-policy. The idea of freedom is based on the duality of freedom of the citizen and the state-polis. Legally and socially secured space is a requirement for the realization of the moral freedom of the individual. Human freedom is always historically and spatially limited in scope and character of the state in which it is realized. Free is each polis that is not under foreign rule. The freedom of citizens stems from the freedom of the polis based on laws as objective standards that oblige people in community life. Within the society there is a mismatch between the natural and social order because that order is defined by laws that are a human, and not divine creation. Freedom is not immanent to lone individuals without their connection with the polis, and therefore does not belong to the slaves nor barbarians ${ }^{6}$.

Socrates, Plato and Aristotle argue that a man should not be subdued to a political order that would morally humiliate him. To a man they considered mandatory only those laws that are based on reason and one should only be subjected to these laws. Freedom is not anarchy, nor can it lead to despotism. Anarchy is unacceptable freedom without the rule of human law and despotism is the rule without freedom. Individual does not gain the freedom automatically but by free choice of good. The possibility of the knowledge of good is immanent only to man as a thinking being, being that elects the purpose of his life and actions by making decisions on the basis of his empirical knowledge of good as a virtue. If these decisions contribute to ethical existence of society, then the real human life contributes to the general theoretical life as the highest form of freedom, happiness and self-sufficiency?

The stoicism freedom is seen as the realization of the internal order of life, as superior being of the spirit as opposed to external circumstances and pressures. In this

\footnotetext{
${ }^{6}$ See: Betermann-Neumann-Backof, Die Grundrechte, Berlin, 1972, p. 11; E. Coreth, The sense of personal freedom, Renewed Life (53) 4 (1998), pp. 391-402; S. Šegvić, Human rights and how to protect them in the constitutions of European countries, Proceedings of PFS, 35/51-52, 1998, p. 601.

${ }^{7}$ See A. Vedross, Abendländisch Rechtsphilosophir, Vienna, 1958, p. 235.
}

\section{CONSTITUTIONAL LAW REVIEW}


we should not separate or oppose natural law and positive law. This is because all men are not equal, because some are free and some are slaves. Their different social status is the result of the differences in their physical and debt characteristics. The political community is obliged to protect the lives and welfare of their citizens and support their natural inclinations. Within the society it is necessary to develop the moral equality, which is based on the reason of all people. It is not moral to rule based on unlimited use of power, but the government should be executed by taking into account the welfare of the whole from which comes the possibility of achieving personal freedom ${ }^{8}$.

With the advent and spread of Christianity the idea of freedom does not disappear, but thinking about the concept of "freedom" gets a fundamentally different character. Already in the Paul's letter to the Romans there is a thought that alongside the divine law there is another, natural, written in the human heart and conscience, and therefore heathens also have available the natural law. However, subsequent development and increasing ideological and political supremacy over sacral and social life led to the cult of religious doctrine and demands that all the ideas be put into function of ecclesiastical authority. Outside the dogma there should be no investigation, philosophy is a maid of theology and the Bible is the ratio scripta. The pantheistic thinking on the unity of nature and God is rejected, because God is over nature. Nature and natural law find their source in God and therefore the Bible becomes a code of natural law ${ }^{9}$.

Secular thinking about freedom as a basic set of human existence arises with the development of capitalism based on private ownership over the means of production. Due to the logic of market economy direct manufacturers here had to be personally available and economically dependent. In capitalism, a country ceases to be the economic base of production, where social minority group on the basis of their ownership rights dictates the market conditions, appropriating a disproportionate part of the newly created value and realizing a profit that is becoming the cause and the goal of economic relations. Industrialization emphasizes the commodity-monetary economy which has inherent freedom of movement of people and capital. Therefore, freedom and equality among people from economic coercion are becoming the basic principles of the new social relations. At the same time freedom and equality, as an expression of the natural rights of man, become the fundamentals of the highest legal and political acts which stipulate the foundations of the new social order. By entering into the

\footnotetext{
${ }^{8}$ From the above it can be concluded that the Hellenistic world and the Roman period did not give a historically significant contribution to the development of thinking about freedom. In particular it should be noted for the Roman society and teaching. The Roman state and law are certainly the biggest achievement in the development of the state and the rights of the slave-owning system. However, the Roman lawyers, no matter how much importance they had for the development of legal thought and the establishment of legal institutions which still apply, have not given their contribution to consideration of human freedom. This is because they were more preoccupied with the pragmatic goal of determining the content of positive law as well as the construction of new, mainly civil institutes. In this the connection of Roman jurisprudence with Stoic natural law failed to activate thinking about freedom, but instead over the property rights held connection with the natural rights ethics.

${ }^{9}$ See B. Perić, Struktura prava, Zagreb, 1990, p. 218.
}

STUDIES AND ARTICLES 


\section{Dubravko LJUBIĆ}

fighting slogan of the French Revolution freedom becomes an abstract category, freed from its concrete relationship with the addressees and is placed on a pedestal of unlimited space of human activity on whose behalf all historical and social ties with the tradition of the divine and aristocratic authority in society are broken. Freedom becomes one of the main criteria for positioning the countries in the new world order, but also individuals within the state organization. It becomes the essence of spirit, the essence of truth, a condition of human knowledge, a tool that allows someone to be what one is and indulge in relationships with other people on the basis of freedom of choice and action. Freedom is also the source of human action whose result is the production of the greatest happiness for the widest range of people. In doing so, human freedom can be restricted only if its consumption can harm others. The principle of prohibition of causing harm to others, as a result of the consumption of their own freedom, in its application to the organization of social relations practically excludes any despotic and authoritarian forms of government that suppress the freedom of the individual and their individuality. Law and government must not impede the freedom of each to participate in social life and dialogue as long as the manifestation of the personality of the individual in society takes care of the ethical values and does not violate the public interest or violation of rights of other entities. Freedom exists in itself, because only free people can realize their potential, while the performance of the content of person's freedom depends on the freedom of other people that live in the community. By allowing freedom to others, and vice versa, it opens the way towards achieving the common liberty. Therefore, human freedom is conditioned by the moral obligation of every individual to live humanly and interpersonally. Freedom can not be used as a means of bringing an end to the freedom of others, but as a prerequisite and a call for a commitment to what is ethically right. People have to build their animal nature into the nature of society, realizing themselves within the community with other free and equal human beings with the help of an institution that they have historically developed and within which they live. Freedom is therefore possible only within a social institution, but not beyond it. Freedom is not a ruthless autocracy of individuals whose actions are led by egoism. There is no freedom without limits, which in society arise from morality. The human self-realization can not be exhausted in a mere egocentrism or domination, but instead the essence is the construction of human personality in the active commitment to another because of oneself. People are free as long as they act, because to be free and act is the same ${ }^{10}$.

The contribution to reflecting the contents of the concept of "freedom" in the $19^{\text {th }}$ century gave the theory of anarchism, which puts human freedom and individuality to the highest place of human existence. According to the anarchists, the government, the

\footnotetext{
10 See: M. Heideger, Vom Wesen der Wahrheit, Frankfurt, 1943, pp. 15-17; J.S. Mill, On freedom, Pennsylvania State University, Portable Document File, 1998, pp. 19-65; H. Arendt, Eseji o politici, Antibarbarus, Zagreb, 1996; Što je sloboda?, pp. 66-84.
}

CONSTITUTIONAL LAW REVIEW 
state and religion are enemies of freedom of the individual and are therefore to be abolished as well as all other traditional institutions that limit the individual and society, and any system that keeps state power as sacred should be abolished. Anarchist theory is egalitarian and anti-hierarchical, and also decentralized. The theory of anarchy advocates self-regulation and voluntary cooperation. Social relations must be conducted freely by negotiated agreements on reciprocal and equal benefits for all parties involved. Instrumentalized government is not reciprocal because the ruler gets more than a subject, but also disturbs the balance of justice. Therefore, the country and its government are opposing the basic principles of social life, while the society must always be in opposition to the state. Government and freedom act as antinomies within each society, each of which is a limitation to the other. Anarchists under freedom mean the absolute respect for the free will of each person. Free people respect other people's freedom and their free will, because to be free is to allow others to be free. Only an unfree person is ready for the abolition of other people's freedoms, to limit other and only such a person gets involved in other people's lives, considering itself responsible for the acts and lives of others. Free people do not need to control or limiting the others. The free person knows only freedom, and to be free means to be without fear, to be responsible for oneself and for ones actions, but also to allow others to be responsible for themselves and their own works. According to anarchists humanity today is not free, and therefore can not know what responsibility, responsibility for oneself and for ones actions is. To be irresponsible, means to shift responsibility to others, to give up freedom in the way determined by these others. By shifting our responsibility, and therefore the freedom into the hands of different power centers, we have agreed to slavery that we mistakenly consider freedom ${ }^{11}$.

$20^{\text {th }}$ century was strongly marked by oppression of nations and peoples. The opposition and incompatibility of interests of political elites, ethnic communities and narrower social groups led to the successive global conflicts and war, but also to establishment of social organizations marked by collectivism and totalitarianism of different signs. Communism, Fascism and Nazism were movements based on the premise that single-mindedness that was evident in the propaganda slogan one nation, one leader, one country, or the dogma of the dictatorship of the proletariat as the only way to achieve a better future and freedom in egalitarianism. Unfortunately, social systems based on the indicated ideas were steeped in the blood of opponents abolishing any form of expression of personality versus the almighty collective. Belonging to the movement becomes the main criteria of the individual's values and driver of every social activity. In totalitarian societies the traditional assumptions of freedom, defined as the natural authority to pursue happiness and to achieve happiness for the widest circle of addressees through economic independence based on the

\footnotetext{
${ }^{11}$ See H. Barclay, People Without Government, elektronickeknjige.com, see Part I, On the Nature of Anarchy, and Part VIII, Do anarchic communities have a message?.
}

STUDIES AND ARTICLES 


\section{Dubravko LJUBIĆ}

guarantee of private ownership, was replaced by the idea of limiting the human potential in the public interest as the basis and driving force for the existence of an omnipotent state. In totalitarian regimes personality of the supporters of the regime is limited to the rules of the community, while the freedom of all others is virtually abolished because as disloyal they not belong to the community and as such are its enemies. Different not only lose their right to equality as a precondition for freedom, but for them there is no equality before the law because their thoughts or actions become persons outside the law. Certain social groups which totalitarian regimes want to get rid of, first within the legal order lose their legal status and become second-class citizens, which is only the beginning of their social or actual liquidation. Life of the different ones depends on the mercy of different centers of power, rather than on legal norms. With the loss of freedom the individual also loses the right to an opinion and to have any social engagement. Totalitarian regimes empirically have proved that one can be deprived even of those rights that were since ancient times considered to be natural and everyone's and that there is no tyrant that could subject that domain to special and excessive restrictions. Inventing genetic or politically suspected individuals or social groups has enabled the establishment of social organization in which some people were born free but others were not. In doing so in every totalitarian regime evident was the intention for the continuous increase of the number of people to which the legal system did not provide the protection that was foreseen for the suitable. Social organizations based on totalitarianism denied the existence of human dignity as a measure of the minimum fundamental rights sphere devoid of every influence and they also denied any thought of a person as an emancipated being, independent of its biological or sociological heritage. In the essence of every totalitarian regime is terror whose ultimate goal is the creation of collectives that due to the realization of their interests, if necessary, sacrifice their parts to the whole. The terror of totalitarianism is easy to mistakenly describe as a consequence of the existence of a tyrant. Totalitarian regimes usually begin their lives as despotic, but by their development the system alienate itself and begins its independent life. Tyranny arises from demolition of laws that ensure a space of freedom that results in the creation of real lawlessness filled with fear and suspicion, in which individuality is lost in the amorphousness of the collective. Society becomes the space without freedom in which there is only fear-driven movement and suspicion-filled action of those who reside in it. Compacting people to each other, totalitarian terror and on it established rule separates the individual components of human freedom narrowing the scope of personal movement and thought process, renouncing individual's choice by determination of their social position that rarely changed for those outside of the preferred nomenclature. With the destruction of freedom and personality of people, terror makes a uniform multitude of individuals out of many different ones who will be forced to act impeccably in achieving the objectives of totalitarianism. With terror, totalitarianism destroys the freedom of the individual by domination of dogma in education and through it in every form of human activity. The 
aim of totalitarian education has never been implanting beliefs, but the destruction of personality and suppression of any creativity. In addition, the field of human activity must be devoid of all virtue, but also all will to perform social duties outside the perimeters needed for system maintenance. Education based on ideology primarily must kill all ethnicity of the individual preparing them therefore for the social role of an executioner or a victim devoid of emotional involvement. In doing so, the very guiding idea is declared a supposedly scientifically based philosophical worldview, no matter how pernicious in its essence it is. Totalitarianism is the negation of liberty as it achieves its fullness by the abolition of any freedom ${ }^{12}$.

\section{Freedom as a constitutional category}

With the advent of constitutionalism established on the basis of general suspectness towards institutionalized authority, knowledge on necessity of determination of protected individual fundamental rights sphere in the highest legal and political act of some social community becomes unquestionable. People are social beings composed of a set of attributes whose integrity is a precondition for their existence. Subtracting any part of the whole concept of a person removes their essence. Since their birth people are also an integral part of society as a whole for whose existence there are also universal standards of existence. Person as an individual can not exist outside society nor can a free society exist without people complete in their essence. Within the society people realize their interests that are linked to their spiritual and material existence. People practice mutual social relations bound by moral norms that have their origin in individual responsibility for ones own deeds based on a distinction between good and evil, and social norms that exist independently of the will of the addressee. Social norms in turn depend on the policy conceived as a product of the will of the centers of social power which limits the freedom of action of an individual where a higher degree of limitation of freedom has a latent intention of turning into a social dictate. Politically shaped dictation stands for socially undesirable disciplined violence and violent discipline. In order to have freedom in a society, it must be integrated. One has to be free because one is a human being, and this can not be achieved in a society that is not free, regardless of the fact whether unfreedom arises due to circumstances which are outside the society or within it. The greatest enemy of freedom is revenge of a dictator or occupier in a state of society which they leave behind. Domestically, the free community is the one that limits the activity of individuals only to the limits of the interests of other members of society. Freedom is not an absolute category but it is an ideal which is to be pursued. All people and collectives want to be free, but in reality only those who know how to be free will live

${ }^{12}$ See H. Arendt, Origins of totalitarianism, Zagreb, 2015, pp. 288-290, 452-464.

STUDIES AND ARTICLES 


\section{Dubravko LJUBIĆ}

free. Freedom does not depend on the will of the government, but on the strength and development of the society, and the overall social reality. There is no particular freedom as a free person can exist only in a society that enables cultural, spiritual, economic and every other social gain over the limits of mere survival. Self-consciousness of society and politics, and the maturity of knowledge about their own values are a prerequisite for individual freedom but also a source of knowledge about the needs of taking responsibility for their own actions. There is no free individual or a free society in which there is no democratic government based on a nation wide action aimed at achieving the general well-being ${ }^{13}$.

\subsection{Freedom in Croatian constitutional and legal system}

The Croatian Constitution in Article $3^{14}$ contains the highest values of the constitutional order, which are the basis for its interpretation. It sets freedom as the primary measure of the definition of each of the constitutional institutes within which to determine social relations, whereby our Constitution does not address the definition of a person as the addressee of the constitutional provisions. The principle of freedom is subsequently determined by specific provisions relating to the forum internum et forum publica of the individual and their derivatives. It can be noticed that in the elaboration of the constitutional principle of freedom our framer of the Constitution departs from the prevailing terms of particular constitutional freedoms sometimes marking them as rights, and sometimes constitutional guarantees ${ }^{15}$. At the same time, evident is the fact that all freedoms have not been listed in Chapter III of the Constitution which deals with the protection of human rights and fundamental freedoms ${ }^{16}$. Also, our Constitution determines the system of human freedoms statically, by narrative sequencing according to the principle of numerus clausus, without any special systematization. With this the area of the protection of freedom loses its ability for expansion without changing the Constitution.

In rigid constitution systems interpretation of the content of the constitution is left to the professional body responsible for preserving the supremacy of the constitution. In our constitutional system, it seems that the practice of the Croatian Constitutional Court does not contribute to overcoming the gap between the constitutional content at the time of its adoption and changes of social relations caused by the rapid social development. From the practice of the Constitutional Court we could conclude that the

\footnotetext{
${ }^{13}$ See I. Oršanić, The vision of Liberty (II), abridged edition, Chicago IL, 1990, pp. 35-60.

14 Freedom, equality, national equality and gender equality, peace, social justice, respect for human rights, inviolability of ownership, conservation of nature and the environment, and a democratic multiparty system are the highest values of the constitutional order of the Republic of Croatia and the grounds for interpretation of the Constitution.

${ }^{15}$ See D. Ljubić, Constitutional concepts of rights, freedoms, guarantees, principles, opportunities and prohibitions, in Croatian Law Review no. 6/11, pp. 1-12.

16 See, for example, Article 1.6 of the Constitution of Republic of Croatia which deals with freedom to form political parties as the essence of freedom of association.
} 
situation in our country with regard to human freedoms is at an ideal level. If we examine the recent Constitutional Court practice we can see that the Constitutional Court in 2015 acted in 4489 cases related to the control of the constitutionality of individual acts of state power. After the completion of proceedings in 2015 a violation of the Constitution was found in 81 cases whereby in one case it was declared, while in 80 cases cassation measures were imposed. Freedom, like physical personal freedom of movement, has been the subject of deciding twice in criminal cases as regards application of detention, and the Constitutional Court decisions rendered in specific cases by their contents represent judicial activism ${ }^{17}$. Furthermore, in one case the subject of decision was a violation of the right to a home ${ }^{18}$, while in all other cases primarily a violation of the right to a fair trial contained in Article 29 of the Constitution was determined. From the above it can be concluded that the Constitutional Court in protecting the fundamental rights sphere, which can be compromised by individual acts of state power, still attaches more importance to the form of the procedure from which the contested decision came rather than its content and possibilities of its impact on the fundamental rights sphere of the individual. Simply put, the Constitutional Court supports the view according to which the fundamental rights sphere of the individual may be violated by procedural steps or the length and quality of reasoning, which in turn greatly deviates from the object and purpose of constitutional adjudication. The role of the Constitutional Court is not to recognize formal or material irregularities in the particular case, but its role is to exclude from the constitutional order in principle constitutionally unacceptable situations or condition. Repeating court proceedings only to correct procedural errors, without the mistakes affecting the fundamental rights sphere of the individual, transforms constitutional justice in the institute that becomes an end in itself. Furthermore, the analysis of decisions of the Constitutional Court shows that even in cases where it determines a violation of freedom, it does not associate any content with this concept, as if it is implied by itself. Violation of freedom is established formally, as a mere consequence of prevention of movement due to the need to carry out court proceedings.

At the conclusion of the ideal exercise of freedom in Croatian society through the period indicated by the practice of the Constitutional Court in assessing the constitutionality of laws and the constitutionality and legality of other regulations. The Court issued rulings in 1269 cases involving the assessment of the constitutionality of a law. Decisions were rendered in three cases in which the matter of the decision was not freedom. In reviewing the constitutionality and legality of other regulations, court made rulings in 1187 cases. In doing so it declared nonconformity with the Constitution and the law in 487 cases, while the cassation measure was imposed in 2 cases. In no case was freedom directly the subject of decision-making. By a review of older rulings of the Court the fact that the current constitutional practice actually follows the pattern

\footnotetext{
${ }^{17}$ See decision U-III-1636/2015 (28 April 2015) and U-III-4259/2015 (24 November 2015).

${ }^{18}$ See decision U-III-3774/2015 (10 December 2015).
}

STUDIES AND ARTICLES 


\section{Dubravko LJUBIĆ}

established by constitutional court practice since the Croatian independence onwards seems transparent. Contents of constitutional rights and freedoms were never completely a subject of processing of Constitutional Court decisions. Finding of a violation of the Constitution according to the Constitutional Court seems putting factual situation under constitutional grounds without thinking about the essence of individual constitutional institutes, whereby the basic constitutional question is bypassed by the debate on peripheral matters ${ }^{19}$.

On the other hand, in reality we are witnessing the conduct of criminal proceedings against a political party for acts that are not defined within the limits of liability specified by the Constitution ${ }^{20}$; or the measure of prohibition of broadcast to a TV station by a body with public law powers that does not have the attributes of jurisdiction, in proceedings in which the legislation allows the driver of the procedure to be the same body that makes the decision, i.e. a proceeding in which the party against whom the measures are being issued is not participating, and all this because of an act whose essential feature is contained in the Constitution and is elaborated in the criminal legislation and whose execution can be determined only by a final judgment of a court with respect to the constitutional presumption of innocence. Furthermore, registration of religious communities is being refused, political opponents are being forcefully hospitalized, and measures of eavesdropping and monitoring are being issued, and all in a constitutionally suspicious way. In the described, but also some other situations, the Constitutional Court did not find it necessary to act, despite broad competencies established by the Constitution and the possession of a set of instruments of action to preserve the supremacy of the Constitution in the company and on its own incentive.

Also, transparent seems the fact that in its practice, although we are a member of the European Union, the Constitutional Court has never considered the freedom in the content which it has under the Charter of Fundamental Rights of the European Union $(2000 / C \text {; 364/01; Nice, 7/12/2000) })^{21}$, i.e. where it is one of the main fields of systematization of a catalog of the fundamental rights sphere that makes the legal order of the Union. The Constitutional Court thus ignores the fact that after the entry into force of the Lisbon Treaty, the Charter has binding force for member countries and its role goes beyond the purely interpretive role in the application of Community Law, because it becomes a source of law in the field of protection of fundamental rights and freedoms ${ }^{22}$. According to the wording contained in the Preamble to the Charter, the Union is founded on the universal values of human dignity, freedom, equality and

\footnotetext{
19 See decisions U-I-3824/2003 etc. (28 April 2004), U-I-1156/1999 (26 January 2000), U-III-180/1995 (22 March 1995), U-III-279/1998 (9 October 1998), U-III-702/2009 (22 May 2013).

${ }^{20}$ See D. Ljubić, The right to freedom of association and the constitutional position of political parties and the existence of their criminal responsibility, in Croatian Law Review no. 3/16, pp. 18-30.

21 "Official Gazette - International Agreements" no. 18/97, 6/99 - Consolidated text and 8/99 - Correction, 14/02. and $1 / 06$.

22 See D. Ljubić, The impact of Croatian accession to the European Union on the constitutional protection of the fundamental rights sphere, in Croatian Law Review no. 6/13, pp. 1-13.
} 
solidarity. Integral principle of freedom worked out in Title II. consisting of Article 6 to Article 19 of the Charter establishes the right to general liberty and security. To be noted here is that the creators of the Charter used the same phrase which contains Article $5 \S 1$ of the Convention for the Protection of Human Rights and Fundamental Freedoms, but without further elaboration of content of this provision. This nomotechnical solution, taking into account the principles for the interpretation of provisions of the Charter contained in its preamble, refers to the definition that the exercise of personal liberty and freedom of development of human beings has in constitutional texts that are based on identical constitutional premises ${ }^{23}$. Charter in the field of integral freedom brings privacy, marriage and family life; protection of personal data; the possibility of expression of thought, conscience and religion; the ability of informing; possibility of assembly and association; educational opportunities and practicing the art and science; the ability to work and choose an occupation; the possibility of acquiring ownership and performance of entrepreneurship; and the possibility of movement, asylum seeking and limiting the possibility of expulsion, deportation or extradition. Pursuant to the above, the Constitutional Court order to protect the constitutionality of those relations, but also in interpretation of all constitutional institutions, should always bear in mind the achievements of integral freedom and basic human freedoms as fundamental values of Croatian constitutional system, according to the diction of Article 3 of the Constitution but also of Title II of the Charter.

\subsection{Freedom as a prerequisite for the development of personality in theory and} practice

In order to conceive the constitutional content of the principle of freedom, and in the absence of domestic constitutional ideals, I deem it necessary to refer to the German constitutional theory and practice that determines operational content for the concept of "freedom". Article 2 of the German Constitution (GG) guarantees personal freedom and freedom of action ${ }^{24}$. In the German constitutional system freedom is a basic feature of human existence and basic human value. It is a prerequisite of any personal rights on the grounds that any legal regulation of human freedom is possible

\footnotetext{
23 See Article 2 of the GG; Article $9 / 2$ or Article 10 of the Spanish Constitution or Article 3/2 Italian Constitution.

24 "(1) Everyone has a right to freely develop their personality if this does not violate the rights of others, constitutional order or the moral law". (2) Everyone has the right to life and physical integrity. Personal liberty is inviolable. These rights can be limited only by the law".

- Provision on the protection right to development of personality is contained in, for example, the Article 3/2 of the Italian Constitution of 1947 and it states: "The task of the Republic is to remove economic and social obstacles which limit the freedom and equality and prevent the full development of human personality and effective participation of all working people in the political, economic and social formation of the country". Also, Article 9/2 of the Spanish Constitution of 1978 states: "State authorities are obliged to create conditions so that the freedom and equality of individuals and groups, in which it is classified, is realistic and effective in removal of obstacles that prevent or impede their full development, and enable the participation of all citizens in political, economic, cultural and social life".
} 


\section{Dubravko LJUBIĆ}

only towards a person, as a relatively free being. German constitutional system simultaneously protects and restricts personal freedom. It sets the limits within which an individual can induce an act or omission, which reduces their choice of behavior. In the German constitutional system freedom is not absolute. Constitutional institute of freedom contains the instruments of its protection as well as the instruments of its limitations. The constitutional wording, according to which personal freedom is inviolable, is not static and unsuitable for changes. The basic and minimum content of this concept consists in social recognition and protection of human dignity and the protection of human personality through the patronage of their physical and mental integrity. By constitutional guarantee of the inviolability of personal freedom protects one of the fundamental constitutional principles that is a prerequisite for the enjoyment of all other particular freedoms. Personal freedom may be limited, but only by law or under the laws enacted by an individual act. At the same time the legitimate purpose of the restriction must be proportionate to the minimum scope of the constitutional guarantee of personal freedom. From personal freedom also arises the right to the free development of human personality. The right to free development of personality is not true classic law that has evolved through Germany's constitutional history. It is a law that finds its political foundation in the civil-liberal conception of "freedom", and it is adopted from historical basic acts. In the German constitutional law the right to develop the personality first appears in the Constitution of the country Hessen from $1946^{25}$.

The right of developing the personality contains a general right of personality and the general freedom of action. General right of personality is a prerequisite to achieving the general freedom of action. General right of personality includes absolutely protected content of private life within the boundaries set by the constitutional order. On the other hand, freedom of action represents an affirmation of human freedom in social contacts, but also in all those situations in which human freedom takes external events to the limits that are set by the rights of others. Free exercise of personality is not a mere exercise of core personality, because it is within this range that we can not violate the rights of others, public order or morality. Developing personality is the ultimate, highest expression of a guarantee of freedom of action, and the highest degree of freedom of human activity in the expression of its personality. The constitutional order protects not only the limited area of personality development, but also every form of human activity, i.e. it protects the total human behavior, not just one of its narrow and specific segments that is as such is specified in the GG. The general freedom of action is a comprehensive starting point of all subjective defensive rights which citizens can point out towards the state. In terms of constitutional concretization the general right of personality is derived from the principle of inviolability of human

\footnotetext{
25 See: K. Hesse, Grundzüge des Verfassugsrechts der Bundesrepulik Deutchland, Heidelberg, 1995, pp. 183-184; S. Rodin, The right to free development of personality in the German constitutional law, Zbornik PFZ, no. $1-2 / 1997$, pp. $136,138,152$.
}

CONSTITUTIONAL LAW REVIEW 
dignity. The bond between these two provisions is the individuality that is contained within them. General right of personality protects the narrow sphere of personal life and the preservation of its fundamental Preconditions that can not be protected by other traditional constitutional institutes. The right to develop personality, interpreted in conjunction with the principle of the inviolability of human dignity, is the passive protection of the role of the state in the protected sphere of the individual. On its own, this law is a dynamic protection as it guarantees to everyone, within the constitutional framework and restrictions, the ability to act on the development of their personality in social relations. A wide interpretation of the content of the right to free development of personality leads to opportunities to get out special rights out of this abstract constitutional basis that have been raised to the level of fundamental rights, i.e. that this provision becomes the starting point for the realization of some of the individual and personal rights ${ }^{26}$.

From the above it can be concluded that in the German constitutional order the realization of the personality of each individual is a comprehensive fundamental right. Practically it is a general measure of all other personal and political freedoms. The exercise of personality, because of its width, is the foundation of subsidiary protection from excessive regulatory burdens. Protection under the right to the development of personality is only provided when no other constitutional norm protects the subjective right of the individual that is considered disturbed. The right to free development of personality in the German constitutional order does not have the character of natural law, but is its positive legal term. Free development of personality can not be pursued at the expense of others, public order or morality. Although conceptually defined very broadly, the right to development of personality is also limited by constitutional criteria. The elaboration of the principle restrictions may be implemented by law or under the law. However, these limitations should not be by nature of their character such to infringe the essential content of the right to development of personality, i.e. they should not restrict the right to development of personality through measures laid down by the principle of proportionality. The right to free development of personality is a corrector of prospective rigid formalism in the approach to the protection of fundamental rights. It allows the realization of the essence of the principle of constitutional state to which its government through prescribing positive law, must not violate the constitutionally guaranteed by fundamental rights and other fundamental values of the constitutional order.

Theoretical interpretations of the scope of the right to free development of personality are based on the practices established by the Federal Constitutional Court in the case of "Elfes" (BVerfGE 6.32) in 1957. In it, the Court points out that GG under the free exercise of personality did not have in mind the mere exercise of core of the personality, because it is within the scope of such a law that the rights of others, public

\footnotetext{
${ }^{26}$ See Maunz-Düring, Grundgesetz, Kommentar, München, 1999, comment Article 2 GG; P. Badura, Staatsrecht, Müenchen, 1986, p. 88.
} 


\section{Dubravko LJUBIĆ}

order or morality can not be violated. From the further actions of the Federal Constitutional Court arises that the provisions of Article 2 of the GG must be interpreted broadly, which affirms the thesis according to which the development of personality is an expression of the general freedom of action. This conclusion stems from the formulation that the development of personality is "an ultimate, highest expression of guarantee of freedom of action" or "the highest degree of freedom of the human activity in the expression of its personality"27. According to the Federal Constitutional Court, the Article 2 of the GG protects not only the limited area of development of personality, but also every form of human activity. That is it protects the whole of human behavior, not just one of its narrow and specific segments as such specified in the $\mathrm{GG}^{28}$. In accordance with the practice of the Federal Constitutional Court the exercise of the personality of each individual is a comprehensive constitutional category and is a general measure of all other personal and political freedoms ${ }^{29}$. The fundamental right of Article 2 of the GG is due to its broadness of subsidiary character and it is applied when no other constitutional norm protects the right to whose violation the party points to ${ }^{30}$.

A wide interpretation of Article 2 of the GG also had important procedural consequences on the constitutional justice. The most important of them is the fact that such an interpretation extended the constitutional basis for the investment of the constitutional appeal ${ }^{31}$. The Federal Constitutional Court has departed from the formal approach to determining the scope of the constitutional basis for filing a constitutional appeal. Since constitutional order is entitled to all the legal rules that in their formal and material sense must conform to the constitution, so should the applicants of the constitutional complaint be allowed to point out to a fact that a legal rule, which limits the general freedom of action, is contrary to the Constitution, i.e. that it does not belong to this constitutional order. Fundamental rights may be restricted to constitutional manner which is controlled by the Federal Constitutional Court. Thus, the constitutional basis for filing a constitutional appeal was expanded to such an extent that the scope of protection is equal to the control of the constitutionality of legislation, and even over that extent in cases of claims that the legislator was not authorized to pass an act $^{32}$.

\footnotetext{
${ }^{27}$ BVerfGE 4, 7; 1, 321; 2, 120; 4, 31.

${ }^{28}$ BVerfGE 74, 129 (151); 75, 108 (154); 54, 143 (146).

${ }^{29}$ BVerfGE 29, 402 (408).

${ }^{30}$ BVerfGE 101, 361; 82, 263 (269); 97, 391 (403); 99, 185 (194); 49, 15 (23).

31 The right to appeal to the Constitutional complaint was not included in the main text of the GG. The protection of fundamental rights through the institute was introduced by the constitutional amendments of 1969. According to Article 93/1/4a. GG "constitutional appeal" may be submitted by anyone who considers that a public authority has violated the fundamental right contained in Article 20/4; Article 33; Article 38; Article 101; Article 103 and Article 104.

${ }^{32}$ In practice of the Federal Constitutional Court, from the interpretation of the provisions of Article 2/1 of the Basic GG derived is the right to inviolability of intimacy [BVerfGE 27, 1 (6)], the right to personal honor [BVerfGE 32, 202 (220)], the right to personal image and spoken word [BVerfGE 34, 238 (246)], right to data
} 
Freedom is a fundamental constitutional principle of organization of social relations. It can exist only in the interaction of the whole and its each component. In an integral way, the principle of freedom is conditional upon the freedom of law, freedom of society and individual freedom and without the existence of any of these levels it can not exist. For the state to be free it must be sovereign, i.e. it must be able to execute authority on its entire territory and protect its interests from all individuals and political threats. The state should not tolerate occupation, aggression or tutoring of any factor nor should it transfer its sovereignty to another, except when it leads to the progress of the whole community, alongside implementation of the formal procedure provided for by the Constitution through a parliamentary body or through forms of direct democracy. At the present stage of development of human society, it is still only an independent, sovereign and thus free state that can ensure that there is freedom in society. The community can be free only within a constitutional state, which has its origin in freedom and personality of the individual, and its organizational consequences in democracy.

The state appears in a democratic society in accordance with the will of the framers of the Constitution in order to achieve public benefit for all or achieve social justice in relation to the immediate social group whose members are in need due to some of their characteristics. Here democracy is not to be perceived in its Aristotelian form as cyclical rule over others, but democracy should be understood as a form of government aimed at achieving the common good. Democracy is marked by the rule of the people, or at least the majority, which must be imbued with individualism, human rights and human dignity as well as cultural and anthropological premise, sovereignty of the nation and the division of power, social justice, tolerance for diversity, open society and multi-party system and the real independence of the courts. The existence of a democratic society excludes the existence of any kind of totalitarianism, but also the existence of terror of minority over the majority based on political, ethnic or any other basis. The action of any social minority group which does not contribute to the common good represents obstruction to the integral freedom as the source of all individual freedoms.

Free state where a free society exists is a precondition of individual freedom. Individual freedom can exist only in a democratic society based on the principles of equality and the ultimate protection of human dignity. The constitutional principle of

protection (BVerfGE 65, 1) and the right to know one's origin (BVerfGE 79, 256). Also, the practice of the Federal Constitutional Court developed the legal view that the provision of Article 2/1 of the GG is the foundation for the realization of individual rights (Einzelbefugnisse), if constitutional order does not provide fencing for the exercise of those rights [BVerfGE 20, 150 (154)]. For example, thus from the general freedom of action arises the freedom of feeding pigeons in public areas, which in turn is limited by reasons of public traffic safety and public order (BVerfGE 54,143), and the same legal basis has the freedom of homosexual relationships, which may be limited by the rules of morality (BVerfGE 6, 389).

STUDIES AND ARTICLES 


\section{Dubravko LJUBIĆ}

equality is the foundation of freedom and social justice in any democratic society. It in its general form requires of the centers of social power to deal with every member of the society as an equal. The principle of equality does not allow the legislature the elaboration of freedoms from the fundamental rights sphere below the minimum content that is guaranteed to each member of the society. Any differentiation of addressees in normative activity must have its legitimate purpose and social goal. Socially relevant circumstances, as based on the distinction, must have in their origin the achievement of overall social benefits or exercise of long-term socially acceptable benefits, both for directly privileged and for those who under a particular legal order are not. Human dignity is a constitutional category that determines each individual as a holder of rights and obligations arising from the basic norms. All individual rights and freedoms have their origin in human dignity. Human dignity on the one hand is the cause for which every individual is guaranteed a specific autonomous area protected from any outside influence, and thus the impact of the government itself. On the other hand, it is a reason and a limiting factor for state authorities in their relations with the individual. Human dignity is not subject to regression, nor any kind of limitation, but an eternal value protected by the rules of most constitutional power. Human dignity is a protection from the possibility of taking legislative activities to the extent that unbearably contradicts the ideas of freedom and justice, and thus the system of basic standards. The content of human dignity is independent of subjective interpretations and perceptions and represents real value of the order that can not be the object of defining. Human dignity exists in itself and is an inalienable part of every human being. It is the foundation of every legal order, its ethics and all the other factors that make the legal system just and prerequisite of existence of freedom and justice that moves the latter values from the domain of theory to their full realization.

Man is a social being composed of a set of attributes whose integrity is a precondition for his existence. To be a human being, the individual must be free just because of being a human being. Personal liberty is an essential feature of a human being. It is the counterbalance of collectivist notions of society and prevents all totalitarian control and directing of people. People can only be free if they exist by the insured cultural, spiritual, economic and every other social gain over the borders of mere survival. Freedom does not depend on the will of the government, but on the strength and development of the society, and the overall social reality. All people want to be free, but only those who know how to be free will truly be free, whereby the degree of realization of individual freedom strongly depends on its intellectual and material resources. Individual freedom allows individuals recognition as human and social beings, regardless of their social irrelevant personal characteristics. It is a protected by the fundamental rights sphere of individuals in social contacts, which gives them the option of choice for social positioning. Individual freedom can be limited by the rights of the same content and other public interest as a result of living in a community. Freedom does not include irresponsible independence of individuals within 
society. Self-awareness and knowledge of their own values are a precondition for individual liberty but also a source of knowledge about the need to take responsibility for their own activities. Individual freedom entails obligations, with the first responsibility and commitment to the freedom of another person. Therefore freedom is not an absolute category because it contains conflict of fields of action and real limitations.

The purpose of individual freedom is the ability to achieve free development of human personality. The right of developing the personality contains a general right of personality and the general freedom of action. General right of personality is a prerequisite to achieving the general freedom of action. General right of personality includes absolutely protected content of private life within the boundaries set by the constitutional order. On the other hand, freedom of action represents an affirmation of human freedom in social contacts, but also in all those situations in which human freedom takes external events to the limits that are set rights of others. Therefore, the development of personality is the ultimate, highest expression of a guarantee of freedom of action, and the highest degree of freedom of human activity in the expression of its personality. 